\title{
LA FRATERNIDAD Y LA DOCTRINA SOCIAL DE LA IGLESIA: PERSONA, CARIDAD Y JUSTICIA SOCIAL
}

\author{
FRATERNITY AND THE SOCIAL DOCTRINE OF THE CHURCH: THE \\ PERSON, CHARITY AND SOCIAL JUSTICE
}

\author{
ESTEBAN ANCHÚSTEGUI IGARTUA*** \\ Universidad del País Vasco UPV/EHU
}

Recibido: 14/04/2019 Aceptado: 19/06/2019

\section{RESUMEN}

Entendida la fraternidad como el lazo de unión entre los seres humanos basado en el respeto a la dignidad a la persona, la igualdad de derechos y la solidaridad de unos hacia los otros, este trabajo hace un repaso sobre la relación que ha tenido históricamente este sentimiento, valor o afecto con la política, donde ha llegado a tener categoría de obligación política. También se hace un recorrido sobre los distintos modelos de comunidad política, haciendo hincapié en las obligaciones y responsabilidades que se generan hacia sus componentes, y se analiza la propuesta de fraternidad cristiana de la mano de la doctrina social de la Iglesia (DSI), que, comprometida con el testimonio de la caridad de Cristo, impulsa el desarrollo integral del ser humano y se involucra con la justicia social. Finalmente, respetando el principio de subsidiaridad, se aboga por la

\footnotetext{
* Miembro del Grupo Consolidado de Investigación tipo A del Gobierno Vasco Biography \& Parliament (IT-1263-19)

Este artículo es el resultado de la estancia de investigación en la Universidad Bernardo O'Higgins (Chile), financiada por la convocatoria de Movilidad del Personal Investigador Doctor (2019) del Gobierno Vasco. MV_2019_1_0008.
} 
colaboración entre el Estado y las distintas fuerzas vivas de la sociedad, entre ellas la Iglesia, para construir una sociedad más justa y que promocione el bien común.

Palabras clave: Fraternidad, obligación, comunidad, caridad, justicia, Doctrina social de la Iglesia (DSI)

\section{ABSTRACT}

I understand fraternity as an array of ties among human beings based on respect and the acknowledgement of the persons' dignity, equal rights and solidarity. This paper discusses the historical relationship between politics and fraternal feelings, values or affections, whereby the former becomes a category of political commitment. Furthermore, I examine several models of political community taking the mutual obligations and responsibilities generated by fraternity as starting point. Then, I discuss Christian fraternity from the point of view of the Social Doctrine of the Church and its compromise with Christ's charity for the integral development of the human beings and social justice. Finally, in accordance with the principle of subsidiarity, I stand for collaboration between the State and civil society, including the Church, to achieve a fairer society that strives for the common good.

Keywords: Fraternity, commitment, community, charity, justice, Social Doctrine of the Church.

Este trabajo pretende reivindicar y rescatar el término cristiano de fraternidad, distinguiéndolo tanto del uso de la expresión fraternidad como sinónimo de hermandad y utilizado habitualmente para aludir a los componentes de una organización (religiosa, militar, universitaria, municipal, benéfica, secreta...) que comparten un mismo proyecto, como del vocablo fraternidad política vinculada en gran medida al concepto político moderno de solidaridad-y que forma parte del programa y el tríptico de la Revolución francesa: libertad, igualdad, fraternidad.

Pero vayamos aclarando conceptos. Así, el vocablo fraternidad, del latín fraternitas, asociado metafóricamente a la "representación de la familia", expresaría la querencia y el ligamen existente entre hermanos o, en su caso, la unión $\mathrm{y}$ afecto que se produce entre quienes se consideran como tales. Por otra parte, el concepto de fraternidad, además de al anteriormente señalado hermandad o confraternidad, también está relacionado o es homólogo a términos como camaradería o amistad. 
Igualmente, quiero incidir en la relación inequívoca que existe entre la fraternidad y dos cualidades, valores o incluso virtudes, como son la confianza y la lealtad. Por un lado, el término confianza se refiere a la opinión favorable sobre la conducta futura previsible que pueda realizar una persona o grupo, lo que lleva al receptor de ese comportamiento a no sentirse inquieto por la respuesta que pueda recibir frente a una determinada situación. Y todo esto se produce porque el "receptor confiado" espera del "actor fiable (leal)" un proceder encaminado en una dirección concreta. Y es aquí donde quiero incidir en el concepto de la obligación política que puede emanar de la fraternidad, que es donde está, a mi entender, el nudo gordiano de esta relación bilateral: el modo como se sustancia el que una mera relación moral pueda adquirir dimensión política, esto es, pasar de una fraternidad "familiar" a una fraternidad "política". O dicho en otros términos: la construcción de la obligación política a través de la fraternidad.

\section{NATURALEZA DE LA FRATERNIDAD EN LA POLÍTICA}

Es evidente que la fraternidad es un valor que remite a otros, del mismo modo que lo hacen principios rectores de sociabilidad como la cooperación, la armonía, la tolerancia, el amor o la amistad. Esta última sería para Aristóteles, como lo señala en la Política, la virtud primordial para cimentar una comunidad política, razón por la cual sería exigible a todos los miembros que la componen. Esa "amistad política" vendría a ser lo mismo que la lealtad hacia (y entre) los ciudadanos, el cemento o nexo social previo a todo vínculo político, en definitiva, la condición prepolítica absolutamente necesaria que indica que hemos elegido vivir en común: "Es evidente, pues, que la ciudad no es una comunidad de lugar para impedir injusticias recíprocas y con vistas al intercambio. Estas cosas, sin duda, se dan necesariamente si existe la ciudad, pero no porque se den todas ellas ya hay ciudad, sino que ésta es una comunidad de casas y de familias para vivir bien, con el fin de una vida perfecta y autárquica. Sin embargo, no será posible esto si no habitan un mismo lugar y contraen matrimonios. Por eso surgieron en las ciudades los parentescos, las fratrías, los sacrificios públicos y las diversiones de la vida en común. Todo es obra de la amistad. El fin de la ciudad es, pues, vivir bien, y esas cosas son para ese fin" (La Política, III, 1280b) ${ }^{1}$.

Cicerón, por su parte, habla de amor al régimen político republicano romano, y señala lo siguiente: "Amamos a nuestros padres, a nuestros hijos, a los parientes, a los amigos, pero sólo la patria comprende a todos y cada uno de los

1 Para ahondar en el concepto de amistad y el cometido de esta virtud en el proyecto de la polis, cf. Mayhew (1997, 73-85) 
que nos son queridos, por ella, ¿qué hombre de bien dudará lanzarse a la muerte para servirla?" (1989, 31). La patria, por tanto, recoge todos nuestros amores (caritates) hasta el punto que en su primer discurso contra Catilina recalca que "la patria me es mucho más querida que la vida" (Catil. 1, 11) y que el amor a la patria impone sobre aquellos que rigen la república la obligación de cuidar por el bien de toda la comunidad. Por consiguiente, el amor a la patria -fundamento de la virtud política (politicam virtutem) - es un amor racional, ya que es amor por un bien (la ciudad libre), algo que es razonable y que cada ciudadano quiere preservar.

Sin embargo, otro estoico como Séneca predica la fraternidad universal y la superación de los reducidos confines de la ciudad o la patria. Y la razón de ello estriba en la dignidad común de todos los hombres, cuyo horizonte de incondicional universalidad los hace ser radicalmente iguales. Séneca patrocina una ética fundada en la conciencia de la finitud y el respeto al prójimo, donde, repudiando cualquier trato de discriminación por motivo de raza o categoría social, los hombres puedan estar unidos por el vínculo de la fraternidad y el amor: homo res sacra homini ${ }^{3}$

El sabio estoico tiene por patria el Universo, aunque el Imperio, la amplitud territorial y la ciudadanía romana ayudan también a esta cosmovisión cosmopolita, en el sentido que el apogeo imperial se retroalimenta y justifica más convenientemente desde una filosofía universalista. En este contexto, los estoicos orientan su reflexión por derroteros más cercanos a la política, y constituyen una escuela de mayor audiencia, tanto en el período helenístico como bajo el Imperio romano; y, asimismo, en el pensamiento occidental posterior, las derivaciones provenientes del estoicismo cruzan el medievo, entran en la edad moderna y llegan hasta nuestros días. Y es en este marco estoico donde la postrera figura republicana de Cicerón cobra un mayor interés, considerado como un intelectual y hombre de Estado que pretende defender la República flexibilizando los angostos y patrióticos límites tradicionales romanos e incorporando la doctrina estoica universalista al ideal aristocrático republicano. La razón de ello estriba en que cuando Cicerón afirma que la moral y la ley -que no es sino la expresión de aquélla- no constituyen una convención humana cambiante, no solamente lo está interpretando dentro de la tradición legalista y realista de los antiguos romanos, apegados al derecho positivo (público o privado ${ }^{4}$ ), sino que toma en consideración otros elementos del

2 "si mecum patria, quae mihi vita mea multo est carior" (1994, 25)

3 "el hombre es un ser sagrado para el hombre" (Séneca 1984, vol. 2, Epístola XCV, 97)

4 Tanto en lo que respecta a las relaciones entre las personas que se reconocen como ciudadanos integrantes de un Estado y se vinculan al interés general (quod ad statum rei romanae spectato) como en lo referente a las relaciones entre las personas entre sí (quod and singulorum utilitatem spectat). 
Derecho romano como el derecho natural ${ }^{5}$ y el derecho de gentes ${ }^{6}$. Así, en adelante, el proyecto ciceroniano (encarnado y optimizado por Augusto en sus propagandísticas Res Gestae Divi Augusti) apunta a que todo hombre posee la forma esencial de lo humano -la razón- y es capaz de adherirse, dando lo mejor de sí mismo, a una ley justa, convertida por este procedimiento en universal.

Así, el universalismo estoico, que considera a los humanos iguales en virtud de su común característica racional, además de formar parte del acerbo político romano irá sentando los fundamentos que sirvan para teorizar el ideal común de la heterogénea sociedad del Imperio. El estoicismo acepta la existencia de un derecho natural, a la que toda justicia se remite en último término, y a cuya primacía no puede dejar de someterse el Estado. En consecuencia, la res publica es una comunidad legal y también moral, un cuerpo que surge del poder colectivo del pueblo para su conservación y donde la autoridad estatal se ejercita a través de la ley.

Este pensamiento tendrá una influencia decisiva sobre los jurisconsultos romanos y sobre la interpretación cristiana del Estado, que, en paralelo a las referencias histórico-políticas a la Roma republicana -señaladas por historiadores como Polibio o Tito Livio-, constituyen el modelo institucional para una corriente del pensamiento político que conforma el acervo hereditario de donde se surten autores de la talla de Maquiavelo, Montesquieu o Rousseau.

Con el desarrollo de la pax romana, el estoicismo y sus semblanzas de fraternidad fueron ampliamente recogidas por el nuevo judaísmo universalista (cristianismo), siendo destacable en este sentido la labor realizada por Pablo de Tarso y sus seguidores, que, en paralelo, cristianizan y dotan de nuevo contenido a muchos de sus principios. Así, para los cristianos, la proclamación de la amistad o el amor hacia todo el género humano, concretada en la ayuda mutua y el uso común de los bienes, ya no es logro de la razón humana, sino que es fruto de un apetito natural de los hombres, en tanto que estos participan de la naturaleza divina. Y su maestro, Jesucristo, es el paradigma del amor por el prójimo, ya que encarna el acontecimiento de máxima generosidad, donde el hijo de Dios se humilla haciéndose hombre y sacrifica y entrega su vida para salvar a todo el género humano. En adelante, sus seguidores, testigos de la Iglesia que él fundó, reconocen a Cristo como Hijo de Dios hecho hombre, creen y confían en él y tienen un ejemplo a seguir en sus enseñanzas - presentadas en el canon bíblico

5 quod natura animalia docuit, todo los que se refiere a lo que la naturaleza o la recta razón nos hace considerar como justo, y es común a todos los seres humanos.

6 ius gentium, lo que es común a todas las personas y se tiene por justo en todas las naciones. 
del Antiguo y el Nuevo Testamento-, obedeciendo la palabra de Dios y amando al prójimo como a uno mismo.

Siempre de la mano y con el ejemplo de Cristo, el discurso cristiano de la fraternidad se propugna a lo largo de numerosos episodios del Nuevo Testamento, promoviendo el amor entre los seres humanos, concebidos como "hermanos" por su condición de hijos de Dios. A este respecto, es el mismo Jesús quien invoca la fraternidad para la humanidad, manifestando antes de morir: "Padre, que todos sean uno" (Jn 17,21).

Además, el cristianismo abre la buena nueva para todos, tengan o no conocimiento de Cristo. Así, en Romanos 2:14-15, San Pablo señala que "cuando los que no son judíos ni tienen la ley hacen por naturaleza lo que la ley manda, ellos mismos son su propia ley. Por su conducta muestran que la llevan escrita en el corazón. Su propia conciencia lo prueba, y sus propios pensamientos los acusarán o los defenderán". Ello significa que la moral no es algo privativo de quienes conozcan la ley de Dios, sino que es connatural a todos los seres humanos, ya que todos tienen conciencia de actuar correcta o incorrectamente. Ello abre el paso a que existe en cada uno de nosotros una moralidad innata, una ley natural dada por Dios a todos los seres humanos. En esta dirección habría que señalar la ingente labor realizada por los humanistas e iusnaturalistas cristianos a partir del siglo $\mathrm{XV}$, entre los que podríamos destacar, entre otros muchos, a Francisco de Vitoria y a Bartolomé de las Casas, o a Francisco Suárez y Hugo Grocio, defensores de que el derecho internacional proviene del derecho natural y del derecho de gentes.

Siempre desde la concepción cristiana, todos estos hitos marcarán la senda que, desde el reconocimiento radical del ser humano -como creación a imagen y semejanza de Dios-y la igualdad de todos los seres humanos -derivada de la unidad de filiación de un mismo padre que es Dios- (Nogueira Alcalá 2003, 1) conducirá al surgimiento y posterior evolución de los derechos humanos o fundamentales, germen de la actual Declaración de los Derechos Humanos. Precisamente en esta línea, el 10 de diciembre de 1973, y con ocasión del XXV aniversario de la Organización de las Naciones Unidas, el papa Pablo VI envió un mensaje al presidente de la Asamblea General de las Naciones Unidas, donde, entre otras cuestiones, señalaba que "los derechos del hombre se fundan en la dignidad reconocida de todos los seres humanos, en su igualdad y fraternidad. El deber de respetar estos derechos tiene carácter universal. La promoción de tales derechos es factor de paz; su violación es causa de tensiones y trastornos, incluso a nivel internacional" $(2003,21)$ para finalizar exhortando a "convertir 
la familia humana en una comunidad mundial de hermanos, donde todos los hijos de los hombres puedan llevar una vida digna de hijos de Dios" $(2003,23)$.

\section{LA FRATERNIDAD COMO OBLIGACIÓN Y LA DOCTRINA SOCIAL DE LA IGLESIA}

Nietzsche, en La genealogía de la moral, afirma que el "auténtico problema" del hombre es poder hacer promesas, convertir en "instinto dominante" el "orgulloso conocimiento del privilegio extraordinario de la responsabilidad, la consciencia de esta extraña libertad, de este poder sobre sí y sobre el destino" (1972, 65-68). Lo que Nietzsche quiso advertir fue que el poder cumplir con las propias obligaciones es un logro personal y cultural, no un hecho natural o garantizado.

Decíamos antes que el "actor fiable o leal" es aquel sujeto de quien se espera un proceder encaminado en una dirección concreta. En este sentido, la lealtad achacable a este actor fiable puede ser privada (motivada en la conciencia de pertenecer a un grupo humano más restringido, y cuyas variables pueden ser muy diversas) o puede tener como referencia un nosotros mucho más amplio (público/político) y hasta puede ser entendida como condición necesaria para la vida pública, afectando y pudiendo ser exigida, por tanto, a todos los miembros de esa comunidad política.

Al teorizar la relación del individuo con su comunidad política, la categoría habitual ha sido y sigue siendo el de obediencia u obligación política. Por tanto, no hay institución política sin obligaciones, hasta el punto de que para la conservación de toda comunidad política es necesario que se cumplan las obligaciones asociadas a ella. De modo que para todo aquel que quiera - de forma expresa o tácita- la continuidad de la institución, surge un deber prima facie de cumplir con las obligaciones. Desde esta perspectiva, podemos definir la lealtad como aquella virtud o disposición que nos recomienda cumplir con nuestras obligaciones y promesas. H. Arendt $(1973,99-100)$ considera ese "asentimiento" o lealtad como la "condición prepolítica" de todos los demás actos políticos, en el sentido de que sin esa capacidad de hacer y mantener promesas o pactos, no habría seguridad respecto a la conducta futura de los ciudadanos en la comunidad política. Es, pues, el consenso requerido para el funcionamiento y la permanencia de cualquier sistema político.

Esta lealtad política alcanza el nivel más alto, más fraternal, en momentos de conflicto y de guerra, cuando en la comunidad política se requiere un mayor grado de espíritu de colaboración -o de sacrificio, si es preciso- en pro de la 
causa común, con apelaciones incluso a una supuesta hermandad comunal originaria. Es en esos casos cuando peor valorada está la falta de lealtad, es decir, la deslealtad, o para referirnos a un término cuya connotación es todavía más peyorativa, la traición. ${ }^{7} \mathrm{Y}$ también nos podemos preguntar si, para estar a la altura de lo que las circunstancias exigen en momentos tan críticos, es necesario realizar actos positivos o es suficiente abstenerse de realizar los negativos, esto es, aquellos que se consideran contrarios a la comunidad. Pongamos un ejemplo. Si para cumplir con la obligación hacia una nación, y la adhesión al enemigo de la misma es considerado como traición, ¿sería suficiente evitar ésta para considerarse fiel a la patria, o es necesario hacer también actos positivos de patriotismo para ganarse ese calificativo? La cuestión radica en que la exigencia mínima que se espera de un compatriota -utilizando la metáfora clásica de la madre patria que protege a sus hijos a la par que estos (percibiéndose como hermanos) tienen el deber de defenderla de sus enemigos- está directamente relacionada con la definición misma de traición que tengamos y el tamaño de la obligación que estemos dispuestos a asumir para eludir esta vileza. Esto es, para ser un hijo fiel a la patria nos debemos "adherir" emocionalmente a ella hasta el sacrificio final, o es suficiente con no pasarse al enemigo.

En cambio, mientras la fraternidad política tiene una dimensión selectiva y las obligaciones correspondientes se vinculan con colectivos como la nación, la clase, la etnia etc., la fraternidad cristiana, sin disminuir un ápice la solidaridad y deber hacia los conciudadanos políticos, se inscribe en un ámbito superior de responsabilidad humana hacia la moralidad y el desarrollo integral de la persona $\mathrm{y}$ de todas las personas, lo que conduce a una práctica de servicio y evangelización.

Ya en los años sesenta Ratzinger publicó un conciso ensayo donde proponía la actualización de la fraternidad cristiana con el objeto de reconducir y superar la tensión existente en la propia tradición bíblica, que a menudo oscilaba entre una fraternidad exclusiva y particularista y una inclusiva y universalista. Esta publicación (Ratzinger 2005a) recoge unas conferencias pronunciadas en Viena por el actual Papa emérito en 1958, donde el entonces joven profesor de teología Joseph Ratzinger reúne y clasifica las diversas acepciones de fraternidad que se recogen en las Escrituras, indicando también el ulterior "ajuste" que la teología cristiana ha realizado de ellas. Además, analiza el concepto histórico de hermano antes y fuera del cristianismo, así como en el cristianismo primitivo; y habiendo planteado el debate acerca de si "el cristianismo no sólo implica

7 De hecho, en caso de guerra, es precisamente el delito de traición uno de los comportamientos más decididamente perseguidos y castigados en la generalidad de los países. 
supresión de límites, sino que él mismo crea una nueva frontera: entre los cristianos y los no cristianos" (Ratzinger 2005a, 85) concluye taxativamente que "la Iglesia es signo de Dios en este mundo" (2005a, 112) y que su tarea consiste en "transmitir al mundo la palabra de Dios acontecida en Cristo, dar testimonio público ante el mundo de la obra salvadora llevada a cabo por Dios públicamente" (2005a, 104), por lo que "los cristianos tienen que ser «luz sobre el candelero» (Mc 4,21) [...] deben brillar como lumbreras en medio del mundo (cf. Flp 2, 15) $[\ldots]$ nunca pueden ni deben conformarse con saludar y amar a sus hermanos, es decir, a los que tienen su misma fe, sino que siguiendo al Señor, que realizó su obra de amor por los que no le conocían ni amaban (cf. Rom 5, 6) amarán a todos los que lo necesitan, sin esperar a cambio ninguna respuesta ni agradecimiento. Pues todo el que precisa de su ayuda es, justamente por eso e independientemente de sus ideas, un hermano de Cristo, más aún, una manifestación del propio Señor (cf. Mt 25, 31-46).” (Ratzinger 2005a, 105).

Aparte de este pequeño extracto de citas, señalaré algunos aspectos del ensayo ${ }^{8}$ que considero relevantes. En primer lugar, al referirse a diversos modelos de fraternidad, Ratzinger subraya que en la fraternidad ilustrada "la hermandad de todos se concibe esencialmente desde abajo, desde la igualdad de origen y naturaleza de todos los seres humanos [...] y las diferencias entre los hombres se deben a una disposición efectiva, es decir, a una arbitrariedad histórica" (Ratzinger 2005a, 32-33), por lo que su único objetivo deseable es la "recuperación [...] de la hermandad originaria de todos los hombres [...] librar a la naturaleza de todos los añadidos de la historia" (Ratzinger 2005a, 33). Esta apelación ilustrada a revertir una naturaleza fraterna previa la considera Ratzinger extremadamente abstracta, más aún sin plantearse la cuestión de "si la naturaleza se encuentra sin más y unilateralmente por encima de la historia" (Ratzinger 2005a, 33) y sin considerar los ámbitos de conducta éticos donde toman fuerza y motivación las acciones fraternas, al mismo tiempo que estima "radical" que en nombre de la fraternidad "desaparezcan todas las barreras y se lleva a cabo la unificación del ethos, que obliga exactamente igual a todos los hombres" (Ratzinger 2005a, 33). Por lo demás, destaca que es preciso recordar que "el programa de la Ilustración, precisamente a partir de la Revolución francesa, fue desmentido radicalmente porque supo distinguir demasiado drástica y sanguinariamente entre el círculo fraterno de los revolucionarios y la lucha externa contra los no revolucionarios, cosa que también el liberalismo, como herencia de la ideología 31-33).

8 Para un análisis más detallado de este ensayo, sugiero la lectura del artículo de D. Gamper (2018, 
ilustrada, supo establecer en la masonería al instaurar un círculo fraternal interno y jerarquizado" (Ratzinger 2005a, 34).

Además, "a partir de la Ilustración, el camino lleva directamente al concepto marxista de fraternidad. [...] De todos modos se perciben diferencias [...] Así, desaparece definitivamente la idea de la paternidad común de Dios; pero también la idea de la humanidad común perderá relevancia ante la decisión [...] a favor de la sociedad socialista. Ahora bien, lo que el socialismo asume [...] en contra del pensamiento ilustrado [...] es el retorno decidido a la distinción de dos ámbitos éticos [...] la humanidad se halla dividida más bien en dos grupos radicalmente antitéticos: capital y proletariado. Entre ellos existe una dialéctica hostil que constituye el ser de la historia. [...] La hermandad de unos incluye, pues, la enemistad de otros" (Ratzinger 2005a, 34-35). Por otra parte, el marxismo comparte con los ilustrados la cosmovisión de que la división de la humanidad es un dato histórico, formulada desde el prisma marxista con la afirmación de que la separación de la historia respecto a la naturaleza es motivada por la alienación del hombre, cuya superación histórica "no hay que buscarla en una exaltación en demasía indeterminada de la toda fraternidad, sino en disciplina estricta en la dura lucha que conducirá hacia la meta. Esa meta es también aquí la fraternidad única e indiferenciada de todos los hombres. Pero el camino es la fraternidad limitada del partido socialista, la confesión de la humanidad dividida en dos" (Ratzinger 2005a, 36).

Frente a estos modelos, y expuesto de una forma muy escueta, la fraternidad cristina que reedifica Ratzinger en su ensayo pretende superar el vaivén entre una fraternidad exclusiva y particularista y una inclusiva y universalista, como se señalaba al comienzo del comentario de esa obra. Con este objeto, Ratzinger realiza una exhortación a los cristianos para que, partiendo de una hermandad con Cristo y su mensaje, desarrollen un afecto que desemboque en una hermandad universal. En este sentido, la trascendencia del mensaje cristiano contiene una crítica al naturalismo ilustrado y establece una fraternidad fundada en la voluntad de Dios, que, "a partir de Cristo, con la nueva humanidad surge también una nueva fraternidad humana que supera y sustituye a la otra [...] Sólo la nueva fraternidad, que tiende a ser universal, constituye una auténtica unidad salvadora. 9 (Ratzinger 2005a, 52). En definitiva, "la limitación interna de los hermanos en Cristo tiene también una vertiente universal. Sólo los que

9 "Por su resurrección tras la muerte del primer Adán, Cristo se convirtió en un nuevo y segundo Adán, en padre primogénito de otra humanidad mejor. [...] Es, pues, evidente que la doble doctrina de Adán constituye realmente una decidida crítica al concepto ilustrado de humanidad, al que sólo otorga vigencia la última humanidad, es decir, la humanidad del «último Adán» (1 Cor 15, 45). Su humanidad no es universal, pero debe y quiere serlo". (Ratzinger 2005a, 52). 
comparten la fe son propiamente hermanos, pero la tarea de estos no consiste en recluirse en su comunidad o en la feligresía, sino que hay una proyección hacia el exterior" (Gamper 2018, 32).

El segundo aspecto que destacaría sería el de "la insignificancia del hermano de Cristo". Ya he señalado anteriormente cómo Ratzinger subraya que los cristianos (siguiendo a Cristo y su obra salvadora, y superando los ámbitos éticos de vida, creencias o frontera entre cristianos y no cristianos) deben amar a los necesitados, porque quien precisa ayuda es hermano de Cristo. Por eso, "en la extraordinaria parábola del juicio final (Mt 25, 31-46) [...] el juez del mundo dice a los que están ante su tribunal que las obras de misericordia que se han hecho o dejado de hacer con los necesitados, a él mismo se lo han hecho o negado. $\mathrm{Y}$ a estos necesitados los denomina sus «hermanos más pequeños» (Mt $25,40)$. No hay nada que indique que sólo se alude aquí a los creyentes [...] sino que se alude claramente a todos los necesitados sin excepción" (Ratzinger 2005a, 46). La enorme importancia de este texto "radica en que la hermandad de Cristo no se cimienta [...] en la comunidad de convicción y elegida por libre decisión, sino en la pobreza y en la necesidad común. [...] Ahora el prójimo no será ya el connacional o el compañero de fe en una religión esencialmente nacional, sino en el compañero en la fe apolítica y espiritual en Cristo. Quien ha leído la parábola del juicio de Mt 25 sabe muy bien el porqué de la respuesta de Jesús en la parábola del samaritano (Lc 10, 30-37). Prójimo es el necesitado que primero me sale al encuentro, pues por el mero hecho de ser necesitado es hermano del Maestro, que se me hace presente en el hombre más insignificante." (Ratzinger 2005a, 47-48).

Y el tercer elemento sería entender y vivir el cristianismo como "apostolado y servicio", lo cual acarrea determinados comportamientos. El cristiano está abierto a la relación con los "demás" y su primer cometido es el de la misión: "Id y enseñad a todas las gentes $(\mathrm{Mt} 28,19)$ y tiene su correspondencia con el carácter público de la propia enseñanza de Jesús" (Ratzinger 2005a, 103). Y el segundo encargo de los cristianos frente a los no-cristianos es el ágape, donde la conducta de los cristianos debe tener una fuerza atractiva y ejemplar, capaz de dirigir su amor a todos los que lo necesitan, sin pedir agradecimiento ni respuesta ${ }^{10}$, y que es fruto del amor especial de Dios para con el hombre: "Porque tanto amó Dios al mundo que dio a su Hijo unigénito, para que todo aquel que cree no se pierda, sino que tenga vida eterna" (Juan, 3, 16). Y en tercer lugar, "el deber más grande que tienen los cristianos para con los no-cristianos es

10 Me remito a la referencia (Ratzinger 2005a, 105), señalada al resumir el ensayo, al comienzo, en el extracto de citas. 
seguir a su maestro en el sufrir por ellos. En el último tramo de su vida, sólo pocos días antes de la pasión, Cristo revistió su mensaje con estas palabras: «Pues tampoco el Hijo del hombre ha venido para ser servido, sino a servir, y a dar su vida en rescate por muchos» (Mc 10, 45). Estas palabras no sólo expresan la ley fundamental de la vida de Jesús, sino también la ley fundamental que preside el apostolado de Cristo." (Ratzinger 2005a, 105-106).

Y con este cuantioso equipaje, señala Blázquez en la Introducción a este ensayo, "la Iglesia ha sido convocada por Dios para ser enviada al mundo, no para vivir confortablemente replegada en sí misma. El deber evangélico de custodiar la identidad de la fraternidad cristiana no es por temor, sino por amor a la humanidad; no se inspira en el miedo al mundo, sino en la obediencia a la misión recibida de Dios." (Ratzinger 2005a, 15-16).

Por último, y a modo de observación final sobre esta publicación, no puedo sustraerme de reproducir una reflexión que también realiza Blázquez en su Introducción, y que me parece sumamente significativa: "El libro de Ratzinger tiene además un valor añadido. Recorrer la historia de la literatura teológica y de los movimientos e iniciativas eclesiales anteriores al Concilio Vaticano II ayuda a leer sus documentos y a interpretarlos con este punto de referencia. Aunque dichos documentos están abiertos a profundizaciones ulteriores y a sugerir nuevas potencialidades al hilo de los acontecimientos, no es legítimo olvidar el tramo del camino que desembocó en ellos" (Ratzinger 2005a, 15-16). Este aspecto es fundamental y ayuda a entender aún mejor el papel decisivo de Ratzinger en la historia más inmediata de la Iglesia. Más adelante señalaré algo al respecto.

Esta reflexión sobre la fraternidad cristiana y su vivencia efectiva está en la base del sentimiento de lealtad fraternal hacia nuestros semejantes. Este afecto, impulsor de determinados comportamientos sociales y virtudes morales, toma carta de naturaleza en la Doctrina Social de la Iglesia (DSI), que ahora trataré de exponer brevemente. Para comenzar, quiero señalar que es bastante recurrente realizar una interpretación sesgada de la DSI, donde, partiendo de que la fraternidad católica se atiene al principio de subsidiaridad, se puede considerar que la DSI únicamente trata sobre "las obligaciones morales y sociales de los fieles, pero no propone soluciones políticas ni arreglos institucionales, fiando la fraternidad a la sociedad civil" (Gamper 2018,30). Pero si esta tendenciosa interpretación nos lleva a pensar que la fraternidad católica se desempeñaría practicando con gratuidad tareas filantrópicas y caritativas, y que estaría desvinculada de cualquier fraternidad secularizada, nos estaríamos engañando absolutamente. En adelante trataré de argumentar el compromiso con la cuestión social 
y el bien común de la DSI, remitiéndome, entre otros autores, tanto a las cuantiosas aportaciones realizadas por Ratzinger (Benedicto XVI) sobre este aspecto (2005[3] y 2009) como a las reflexiones efectuadas por personalidades católicas vinculadas a la economía como Zamagni ${ }^{11}$, el cual, desde el encuadre de la Encíclica Veritatis Splendor (1993, § 78), cuando esclarece que "la moralidad del acto humano depende sobre todo y fundamentalmente del objeto elegido racionalmente por la voluntad deliberada"12 señala que "la DSI ubica su punto axial en el «estar con». El sentido de la ética del bien común consiste en que para poder comprender la acción humana es necesario ponerse en la perspectiva de la persona que actúa y no en la perspectiva de la tercera persona o del espectador imparcial" $(2009,14)$.

La clave del DSI está en recordarnos que la fraternidad no se remite a la esfera privada o filantropía (como la practicada en instituciones como la masonería), sino que, de la mano de un humanismo pluridimensional, nos impulsa a comprometernos en todos los ámbitos sociales, sin desdeñar el de la propia economía. De este modo, promoviendo una economía responsable sometida a las leyes y encauzada por la democracia al bien común, "el mercado no es combatido o "controlado», sino que es visto como un momento importante de la esfera pública -esfera que es bastante más vasta que la estatal- el cual, si es concebido y vivido como lugar abierto a los principios de la reciprocidad y del don, puede construir la «ciudad»". (Zamagni 2009, 13).

Este modelo de fraternidad cristiana, que se expresa en esos alegatos, está extraordinariamente dirigido a la cuestión sangrante que vivimos en nuestros días en lo que se refiere a la proliferación escandalosa de las injusticias sociales producidas por el sistema neoliberal de la globalización actual, y reafirma el compromiso de la DSI con estos tiempos y sus necesidades.

Las sociedades modernas están sujetas a una tendencia donde la creciente mercantilización del mundo ha hecho que nada quede a resguardo del alcance del dinero, incluida la vida humana. Kant (1989) señalaba que, al margen del reino de "las cosas que tienen precio", tenemos que pensar el de las que "poseen una dignidad". Y solamente los seres humanos, y sólo precisamente en la medida de que son sujetos racionales libres, poseen dignidad. Es evidente, por tanto, la dimensión social de la dignidad.

Entretanto, frente a expresiones meramente declarativas de la versión universalista ilustrada respecto a modelos que, siguiendo reglas de la racionalidad

11 También citado por Gamper, Stefano Zamagni es miembro de la Asociación de Desarrollo y Capacidad Humana (HDCA) y Presidente de la Academia Pontificia de Ciencias Sociales.

12 Santo Tomás, Cf. Summa Theologiae, I-II, q. 18, a. 6 
medios-fines, consideran que la moralidad no vendrá ya dada por la intención de un objeto sino por la intención de las consecuencias que el agente quiere hacer surgir (Weber 1992), o ante las más recientes controversias sobre igualdad de resultados-igualdad de puntos de partida con ocasión del debate acerca la crisis y rediseño de la Welfare State, se alza, con extraordinaria lucidez, el mensaje cristiano a través de la fraternidad. Así, con el antecedente del Rerum Novarum (1891) de León XIII (primera encíclica social de la Iglesia, donde se denunciaban las condiciones de las clases trabajadoras, se apoyaba el derecho a formar uniones o sindicatos o señalaba los principios para buscar la justicia social en la economía y la industria) y a partir de la temática del "desarrollo de los pueblos" planteada por Pablo VI en el Populorum progressio (1967), elemento pilar de la DSI y del Concilio Vaticano II, Benedicto XVI da a conocer en 2009 la carta encíclica Caritas in veritate.

Este documento supone un hito importante para la Iglesia del presente, donde, con afirmaciones tan contundentes como "hoy es preciso afirmar que la cuestión social se ha convertido radicalmente en una cuestión antropológica" $(2009, \S 75)$, se reivindica y propone la fraternidad cristiana como el modelo a seguir para una superación de las injusticias y desigualdades en el actual contexto globalizado, al mismo tiempo que su práctica y desarrollo están indisolublemente vinculados a la Doctrina Social de la Iglesia. De hecho, con esta encíclica Benedicto XVI concreta y culmina la tarea de reconstrucción e interpretación de la fraternidad cristiana y la fe católica que, desde una perspectiva teológica, había iniciado cincuenta años atrás en el ensayo comentado antes (Ratzinger 2005a). En este sentido, como señalaba anteriormente, con este Pontífice se recorre y completa un período de transición donde la fraternidad cristiana se convierte en un instrumento fundamental para recorrer la senda de las aspiraciones de renovación de la teología moral plasmadas en el Concilio Vaticano II, asumiendo unas exigencias que suponen un categórico avance y una meritoria aportación en el camino de su actualización, sin implicar, en ningún caso, rechazo, paralización o conclusión alguna a este inevitable proceso de renovación.

Partiendo de que "la verdad originaria del amor de Dios, que se nos ha dado gratuitamente, es lo que abre nuestra vida al don y hace posible esperar en un desarrollo de todo el hombre y de todos los hombres, en el tránsito de condiciones menos humanas a condiciones más humanas $(2009, \S 8)$, la encíclica asume las dos aspiraciones de renovación de la teología moral católica del Concilio Vaticano II, como son la doctrina del hombre como imagen de Dios, "Dios es el garante del verdadero desarrollo del hombre en cuanto, habiéndolo creado a su imagen, funda también su dignidad trascendente y alimenta su anhelo 
constitutivo de «ser más»"“(2009, §29), y la idea bíblica del seguimiento de Cristo: "El testimonio de la caridad de Cristo mediante obras de justicia, paz y desarrollo forma parte de la evangelización, porque a Jesucristo, que nos ama, le interesa todo el hombre". $(2009, \S 15)$,

Para Benedicto XVI una sociedad en la que se disuelve el principio de fraternidad no tiene futuro ni es capaz de progresar: "Sin la perspectiva de una vida eterna, el progreso humano en este mundo se queda sin aliento. Encerrado dentro de la historia, queda expuesto al riesgo de reducirse sólo al incremento del «tener»" $(2009, \S 11)$. En la Encíclica se enfatiza sobre el alcance y las consecuencias de la responsabilidad terrena del actuar cristiano, "porque ninguna estructura puede garantizar dicho desarrollo desde fuera y por encima de la responsabilidad humana" $(2009, \S 17)$ y, haciendo referencia a encíclicas de sus predecesores, el Santo Padre subraya que el móvil religioso del actuar reside en lo trascendente, de modo que el criterio último de moralidad de las acciones tendrá que estar situado en la consecución del bien humano que se pretende sin olvidar las exigencias éticas de la acción: "Los «mesianismos prometedores, pero forjadores de ilusiones» basan siempre sus propias propuestas en la negación de la dimensión trascendente del desarrollo, seguros de tenerlo todo a su disposición" (2009, §17).

"La doctrina social de la Iglesia responde a esta dinámica de caridad recibida y ofrecida. Es caritas in veritate in re social" $(2009, \S 5)$, en tanto es "fruto de la sabia reflexión magisterial y expresión del constante compromiso de la Iglesia, fiel a la Gracia de la salvación de Cristo y a la amorosa solicitud por la suerte de la humanidad" (Consejo Pontificio "Justicia y Paz". Compendio de la Doctrina social de la Iglesia [En adelante CDSI] 2005, §8).

La expresión "doctrina social" se remonta a Pío XI (encíclica Quadragesimo anno, 1931). Designa el corpus doctrinal referente al trabajo y reflexión desarrollado en la Iglesia a partir de la encíclica Rerum novarum (1891), de León XIII, publicándose en 2004 el Compendio de la Doctrina Social de la Iglesia (CDSI), organizado por el Consejo Pontificio "Justicia y Paz" bajo encargo de Juan Pablo II, y que presenta de forma sistemática el contenido de la doctrina social de la Iglesia que se ha producido hasta ese momento.

En el documento se recuerda que "La Iglesia camina junto a toda la humanidad por los senderos de la historia. Vive en el mundo y, sin ser del mundo (cf. Jn 17,14-16), está llamada a servirlo siguiendo su propia e íntima vocación" (CDSI, 2005, §18), siendo su objetivo el desarrollo humano integral, esto es, "el desarrollo de todo el hombre y de todos los hombres" (Pablo VI, encíclica Populorum Progressio, 1967, §42; Benedicto XVI, encíclica Caritas in veritate, 
$2009, \S 8)$. Siendo la persona el centro de la enseñanza social católica, y recalcando que el ser humano es "único e irrepetible en su individualidad [y] todo hombre es un ser abierto a la relación con los demás en la sociedad" (CDSI, $2005, \S 61$ ), la DSI considera que, para garantizar su bien individual, familiar o comunitario, toda persona está emplazada a realizarse absolutamente, impulsando el desarrollo y el bien de la sociedad en la que está inserta.

Una sociedad únicamente será justa si sabe respetar la dignidad de cada persona, y el respeto a la dignidad humana pasa necesariamente por considerar al prójimo como otro yo, sin exceptuar a nadie: "Detrás está que cada persona ha sido deseada. Cada persona es idea de Dios" (Ratzinger 2005b, 71). Por ello, aunque la DSI es universal, la vida del otro debe ser tomada en consideración, es única y necesaria para construir el bien de todos: "Todo lo que en principio está ahí fácticamente alberga un plan y una idea [...] Sí, tal es la convicción fundamental del cristianismo. Cuando la Sagrada Escritura presenta gráficamente la creación del hombre -con Dios el alfarero, que lo forma y le insufla el espíritu-, eso está pensado arquetípicamente para cada individuo" (Ratzinger 2005b, 71-72). Por ello, como la dignidad de cada persona es inalienable, habrá que tomar en consideración dotarla de los medios necesarios para mantenerla dignamente, "porque el principio, el sujeto y el fin de todas las instituciones sociales es y debe ser la persona humana, la cual, por su misma naturaleza, tiene absoluta necesidad de la vida social" (Gaudium et spes, 1965, §25) de donde se deduce que "el orden social [...] y su progresivo desarrollo deben en todo momento subordinarse al bien de la persona, ya que el orden real debe someterse al orden personal, y no al contrario". (Gaudium et spes, 1965, §26)

En esta línea, la DSI define el bien común como "el conjunto de condiciones de la vida social que hacen posible a las asociaciones y a cada uno de sus miembros el logro más pleno y más fácil de la propia perfección" (Gaudium et spes, 1965, §26), aclarando que "no consiste en la simple suma de los bienes particulares de cada sujeto del cuerpo social. Siendo de todos y de cada uno es y permanece común, porque es indivisible" (CDSI, 2005, §164), y cuya promoción (la del bien común), teniendo en cuenta la cada vez mayor interdependencia y universalización, "sólo juntos es posible alcanzarlo, acrecentarlo y custodiarlo" (CDSI, 2005, §164). En definitiva, para ponerse auténticamente al servicio del ser humano y su dignidad, la sociedad debe poner como meta el bien común, posibilitando al ser humano todo lo que éste precise para vivir una existencia plenamente humana, como son "el alimento, el vestido, la vivienda, el derecho a la libre elección de estado y a fundar una familia, a la educación, al trabajo, a la buena fama, al respeto, a una adecuada información, a obrar de 
acuerdo con la norma recta de su conciencia, a la protección de la vida privada y a la justa libertad también en materia religiosa" (Gaudium et spes, 1965, §26).

$\mathrm{Y}$ aquí es donde interviene el verdadero sentido del principio de la subsidiaridad que propugna la DSI. Comienza indicando que "la exigencia de tutelar $y$ de promover las expresiones originarias de la sociabilidad es subrayada por la Iglesia en la encíclica "Quadragesimo anno», en la que el principio de subsidiaridad se indica como principio importantísimo de la «filosofía social»" (CDSI, 2005, §186), para continuar esclareciendo que "no se puede quitar a los individuos y darlo a la comunidad lo que ellos pueden realizar con su propio esfuerzo e industria" (ib.) ni tampoco es justo "quitar a las comunidades menores e inferiores lo que ellas pueden hacer y proporcionar y dárselo a una sociedad mayor y más elevada" (ib.). La cuestión clave, por tanto, es que "toda acción de la sociedad, por su propia fuerza y naturaleza, debe prestar ayuda a los miembros del cuerpo social, pero no destruirlos y absorberlos" (ib.) por lo que "todas las sociedades de orden superior deben ponerse en una actitud de ayuda («Subsidium») - por tanto de apoyo, promoción, desarrollo- respecto a las menores" (ib.). Sería, por tanto una subsidiaridad en sentido positivo, como ayuda económica, institucional, legislativa, ofrecida a las entidades sociales más pequeñas, lo que acarrearía implicaciones en negativo, restringiendo e imponiendo al Estado a abstenerse en el espacio vital de las células menores y esenciales de la sociedad, porque su iniciativa, libertad y responsabilidad nunca deben ser suplantadas (cf. CDSI, 2005, §186).

Además, es muy destacable y actual señalar cómo el principio de subsidiaridad contrasta con "las formas de centralización, de burocratización, de asistencialismo, de presencia injustificada y excesiva del Estado y del aparato público", como ya lo había señalado Juan Pablo II en su encíclica Centesimus annus (1991, §48): "Al intervenir directamente y quitar responsabilidad a la sociedad, el Estado asistencial provoca la pérdida de energías humanas y el aumento exagerado de los aparatos públicos, dominados por las lógicas burocráticas más que por la preocupación de servir a los usuarios, con enorme crecimiento de los gastos" (recogido en CDSI, 2005, §187). De este modo, advirtiendo que el principio de subsidiaridad queda gravemente dañado por "la ausencia o el inadecuado reconocimiento de la iniciativa privada, incluso económica, y de su función pública, así como también los monopolios" se propugna por el "equilibrio entre la esfera pública y privada, con el consecuente reconocimiento de la función social del sector privado; una adecuada responsabilización del ciudadano para «ser parte» activa de la realidad política y social del país" (CDSI, 2005, §187). 
Asimismo, la DSI apela por la solidaridad como "principio social y como virtud moral" (CDSI, 2005, §193), ya que "confiere particular relieve a la intrinseca sociabilidad de la persona humana, a la igualdad de todos en dignidad $y$ derechos [y] al camino común de los hombres y de los pueblos hacia una unidad cada vez más convencida" (CDSI, 2005, §192). La solidaridad, por tanto, se presenta bajo dos aspectos complementarios, "en su valor de principio social ordenador de las instituciones" (CDSI, 2005, §193) y como "una verdadera y propia virtud moral" (id.) encarnada en "la determinación firme y perseverante de empeñarse por el bien común; es decir, por el bien de todos y cada uno, para que todos seamos verdaderamente responsables de todos" (id.). En este sentido, "la solidaridad se eleva al rango de virtud social fundamental, [en tanto] se coloca en la dimensión de la justicia, [está] orientada por excelencia al bien común, y [se expresa] en la entrega por el bien del prójimo, [...] dispuesto a "perderse", en sentido evangélico, por el otro en lugar de explotarlo, y a "servirlo" en lugar de oprimirlo para el propio provecho" (id), absolutamente en consonancia con la vida y el mensaje de Jesucristo (cf. $M t$ 10,40-42; 20, 25; Mc 10,42-45; Lc 22,25-27, Jn 15,13 o Flp 2,8).

La enseñanza social católica, en su caminar hacia el desarrollo integral del ser humano, defiende que las injusticias de todo tipo sólo pueden encauzarse superando "las estructuras de pecado que dominan las relaciones entre las personas y los pueblos (CDSI, 2005, §193) para transformarlas "en estructuras de solidaridad" (id.), tanto para superar "las fortísimas desigualdades entre países desarrollados y países en vías de desarrollo" (CDSI, 2005, §192) como los abusos manifiestos existentes en el interior de los distintos países, "mediante con la creación o la oportuna modificación de leyes, reglas de mercado y ordenamientos (CDSI, 2005, §193), apelando "al compromiso en esta dirección [...] allí donde prevalece una lógica de separación y fragmentación” (CDSI, 2005, $\S 194)$.

La DSI, considera, en definitiva, que "el principio de subsidiaridad debe mantenerse intimamente unido al principio de la solidaridad y viceversa" (2009, $\S 58)$. Tanto la integración de estos dos principios como su percepción y aplicación conjunta son absolutamente fundamentales, "porque así como la subsidiaridad sin la solidaridad desemboca en el particularismo social, también es cierto que la solidaridad sin la subsidiaridad acabaría en el asistencialismo que humilla al necesitado" (ib), comportamientos estos que, bajo la máscara de loables intenciones, acarrean consecuencias muy perniciosas.

Además, la enseñanza social católica es una herramienta fundamental de evangelización, que anuncia y actualiza el mensaje de Jesús, en ámbitos 
esenciales de la existencia del ser humano, como la familia, "célula primera y vital de la sociedad" (CDSI, 2005, §211); el trabajo, "el actuar del hombre en cuanto ser dinámico" sin olvidar nunca que "la persona es la medida de la dignidad del trabajo" (CDSI, 2005, §270-271); la economía, "la formación de la riqueza y su incremento progresivo [...] orientado al desarrollo global y solidario del hombre y de la sociedad en la que vive y trabaja" (CDSI, 2005, §334); la política; "la comunidad política deriva de la naturaleza de las personas" que "encuentra en la referencia al pueblo su auténtica dimensión" y donde "la autoridad politica debe garantizar la vida ordenada y recta de la comunidad, sin suplantar la libre actividad de los personas y de los grupos", la cual debe estar regida por una auténtica democracia, "que no es sólo el resultado de un respeto formal de las reglas, sino que es el fruto de la aceptación convencida de los valores que inspiran los procedimientos democráticos: la dignidad de toda persona humana, el respeto de los derechos del hombre, la asunción del «bien común» como fin y criterio regulador de la vida política" (CDSI, 2005, §384, 385, 395, 407); la comunidad internacional, basada en los "mismos valores que deben orientar la de los seres humanos entre sí: la verdad, la justicia, la solidaridad y la libertad" debe "consolidar un orden internacional que garantice eficazmente la pacífica convivencia entre los pueblos, 436, donde, "para resolver los conflictos [...] que comprometen la estabilidad de las Naciones y la seguridad internacional, es indispensable pactar reglas comunes derivadas del diálogo, renunciando definitivamente a la idea de buscar la justicia mediante el recurso a la guerra" (CDSI, 2005, §433, 436, 438); el medio ambiente, "una responsabilidad que debe crecer, teniendo en cuenta la globalidad de la actual crisis ecológica y la consiguiente necesidad de afrontarla globalmente", que, como " $p a-$ trimonio común del género humano, se extiende no sólo a las exigencias del presente, sino también a las del futuro", todo lo cual nos debe obligar a "un efectivo cambio de mentalidad que lleve a adoptar nuevos estilos de vida [...] presididos por la sobriedad, la templanza, la autodisciplina, tanto a nivel personal como social. [...] La cuestión ecológica [...] debe ser, principalmente, una vigorosa motivación para promover una auténtica solidaridad de dimensión mundial" (CDSI, 2005, $\$ 466,467,486)$; o la paz, "un valor y un deber universal, [...] no es simplemente ausencia de guerra, ni siquiera un equilibrio estable entre fuerzas adversarias [...] sino que requiere la edificación de un orden según la justicia y la caridad”. (CDSI, 2005, §494)

En definitiva, siendo la persona el centro de la enseñanza social católica, único e irrepetible en su individualidad y abierto a la relación con los demás en la sociedad, si queremos entendernos en cuestiones de orden socio-político sobre una base común compartida "la ley moral universal escrita en el corazón del 
hombre es aquella suerte de 'gramática' que sirve al mundo para afrontar la discusión acerca de su mismo futuro (Juan Pablo II 1995)" (Zamagni 2009, 11). Con este impulso, la DSI emplaza al ser humano a realizarse integralmente, impulsando el desarrollo y el bien de la sociedad en la que está inserta. Y toda esta labor, como señala Zamagni, no ha sido un trabajo baldío, porque "después de un largo periodo detiempo durante el cual la célebretesis dela secularización parecía haber dicho la última palabra sobre la cuestión religiosa, al menos en lo que concierne al campo económico" $(2009,14)$, las cosas parecen haber cambiado, y "a partir de la afirmación de que las creencias religiosas son de importancia decisiva para forjar los mapas cognitivos de los sujetos y para plasmar las normas sociales de comportamiento [...] no es tan difícil comprender el retorno al debate cultural contemporáneo de la perspectiva del bien común, verdadera figura de la ética católica en el ámbito socio-económica" (id). Y ello únicamente puede ser debido, enfatiza Zamagni, a que "como Juan Pablo II dejó en claro en varias ocasiones, la Doctrina Social de la Iglesia (DSI) no debe ser considerada una teoría ética ulterior a las muchas que ya están disponibles en la literatura, sino una «gramática común» a ellas, porque se basa en un punto de vista específico, el de cuidar del bien humano" $(2009,14)$.

\section{SENTIMIENTOS Y OBLIGACIÓN POLÍTICA. MODELOS DE COMU- NIDAD}

La obligación política, como señalaba al comienzo del apartado anterior, tiene un nivel afectico e imaginario profundo que puede requerir de un nivel de exigencia destacable, por lo que está muy mediatizada por la convicción y estado de ánimo de los obligados, rasgo éste que nos lleva a otro aspecto fundamental al momento de asumir las obligaciones: el lugar de los sentimientos en la política.

Una de las formas de entender la filosofía política puede ser la de comprenderla como una patología política, y observar el lugar que las pasiones o los sentimientos (lo que suele tacharse de "irracional") tienen en ella. Al analizar los presupuestos subjetivos de la fraternidad política habrá que ver si ésta, en tanto en que propia del ser humano, resulta una pasión política (si es una vía de legitimación afectiva del poder), o si, teniendo su origen en un sentimiento, puede desembocar en una disposición ya razonable y con pretensiones de universalidad. Dicho de otra manera, es interesante analizar el paso entre la fraternidad como sentimiento (natural, espontáneo, inconsciente, etc.) a la fraternidad como actitud (consciente, reflexiva, deliberada, etc.), diferenciando, en la línea sugerida por Tocqueville (1988, I, 222-223), dos modelos de amor a la patria y 
a los compatriotas que la constituyen: el puramente instintivo ("que tiene su fuente principal en ese sentimiento irreflexivo, desinteresado e indefinible que ata el corazón del hombre al lugar de su nacimiento") y el "patriotismo reflexivo". Éste último consistirá en "hacer que el pueblo vea como una sola cosa el interés individual y el interés del país, pues el amor desinteresado a la patria huye para no volver." Y continúa: "Nace éste de la ilustración, se desarrolla con ayuda de las leyes, crece con el ejercicio de los derechos y acaba, en cierto modo, confundiéndose con el interés personal. Si un hombre comprende la influencia que el bienestar del país tiene sobre el suyo propio [...] opino que el medio más poderoso y quizá el único que nos queda, de interesar a los hombres en la suerte de su patria es el de hacerlos participar en su gobierno" (ib.).

Sería conveniente, por tanto, esbozar una breve reflexión sobre las pasiones políticas, un tema que, sobre todo en los tiempos democráticos que vivimos, sufre de un injustificado olvido. En general, todos los filósofos han concebido la política como escenario (y a veces remedio) de las pasiones humanas, el material que los gobiernos debían calmar o satisfacer, casi siempre domeñar y dirigir, y en ocasiones exaltar. Pero si la política coincide en buena parte con la permanente tarea de racionalización de lo irracional en la vida pública de una sociedad, el quid reside entonces en restituir la importancia de lo irracional en la política.

Si bien no resulta fácil señalar una nítida demarcación entre pasiones políticas y pasiones sociales, las pasiones que aquí denomino políticas son elementos primordiales de lo que Tocqueville llamó "estado social": "Las sociedades políticas son, no lo que les hacen las leyes, sino lo que les preparan a ser de antemano los sentimientos, las creencias, las ideas, los hábitos de corazón y de mente de los hombres que las componen, lo que el temperamento y la educación han hecho de ellos" (1988, II, LXII). El estado social (que en ocasiones se identifica con la sociedad civil) da forma, a su vez, al Estado político. Y, una vez producida una transformación en el estado social, se produce la adecuación, lenta o apresurada, de las instituciones legales y políticas.

Pues bien, cabría clasificar las pasiones políticas entre aquellas que son constitutivas de lo político como tal y entre las que, entre otras opciones, impulsan, modifican o soportan la política en su diversidad de opciones. Las primeras pertenecen a la dimensión esencial de lo político y dan lugar a sus estructuras últimas; destacando, sobre todas ellas, el afán de poder, el miedo y la esperanza. Las otras serían, por un lado, aquellas pasiones capaces de producir efectos políticos de cualquier clase, es decir, cambios en la organización y distribución del 
poder en una comunidad. Aunque muy cercana al primer nivel, la fraternidad política parece encajar mejor en la segunda categoría.

Ciertamente, los motivos en que se funda este apego a la comunidad política y a sus componentes pueden ser variados. Serán, de una parte, motivos prudenciales, instrumentales o pragmáticos cuando el Estado se entiende como protección individual contra el estado natural. Tal sería la posición de Hobbes y el liberalismo clásico, que hoy tendría como referente al ideal de Estado mínimo, y donde la obligación política sería tan sólo requisito de supervivencia o producto del temor al castigo. Pero también ha de considerarse que la obligación política de la solidaridad (o de la fraternidad en su caso) pueda basarse en otros factores emotivos, como la que se debe al Estado en tanto éste es concebido como protección de una comunidad natural previa de pertenencia vinculado a una lealtad comunitaria. Asimismo, este compromiso puede ser producido por motivaciones racionales o de derecho que nos disponen a una lealtad al Estado en tanto éste se constituye como instancia del desarrollo de los derechos individuales (nos referiríamos más al ideal de una política democrática asociado a una lealtad más cívica), en la que encajaría mejor la obligación política de la solidaridad. Considero que es éste el nudo gordiano para delimitar el ámbito específico de las obligaciones políticas -y el de la fraternidad política en su caso- buscando el encaje de las distintas obligaciones con los diversos modelos de comunidad política. A lo largo de esta descripción se irán señalando distintas nociones políticas e identitarias que sin duda nos evocarán aspectos significativos que Ratzinger señalaba al analizar críticamente los modelos de fraternidad ilustrada o marxista en el ensayo que hemos comentado anteriormente, lo que nos revelará el grado de influencia, afinidad o connivencia existente entre cada uno de estos modelos de comunidad política con los diversos arquetipos y cosmovisiones antropológicas imperantes en la sociedad, del mismo modo que nos proporcionará elementos para esclarecer los valores y creencias que subyacen en cada forma de organización política.

\section{LA COMUNIDAD LIBERAL Y LA SUPREMACÍA DE LOS DERECHOS}

Una forma usual de referirse al liberalismo como forma de gobierno es describiéndola como aquella comunidad política que está al servicio de la identidad individual. Esta concepción política da prioridad ontológica al individuo, y es a partir y en función de él como se explica cualquier entidad colectiva. El liberalismo, por tanto, enfatiza el individuo -en cuanto sujeto privado- así como su capacidad para trascender la identidad colectiva, siendo la defensa, el 
reconocimiento y la garantía pública de los derechos individuales la piedra angular desde donde se percibe y practica la política.

El liberalismo concibe los derechos del ciudadano sobre una base universalista, como derechos del hombre. Esta visión subyace en el contenido de las revoluciones americana y francesa, lo que da origen a la ciudadanía moderna. Los textos constituyentes de ambas propuestas fundamentan los derechos de los ciudadanos, no sobre méritos o condiciones particulares de adscripción, sino sobre su dignidad como hombres ${ }^{13}$. Desde esta perspectiva, los derechos (al contrario de los privilegios) no están subordinados ni al linaje ni a la jerarquía "natural", como tampoco lo están condicionados a ser nativo de una ciudad o territorio concreto. El criterio es que somos iguales por naturaleza, lo que, como seres humanos dotados de dignidad, nos hace ser acreedores del disfrute de ciertas condiciones de vida. Los derechos fundamentales, por tanto, no están supeditados a los rasgos privativos-como, por ejemplo, la ascendencia, la raza o la lengua-sino que deben ser la garantía para el desarrollo de las capacidades que posee cada ser humano, tanto para ejercitar su autonomía como para desenvolver su vida en común.

Por tanto, las declaraciones de Derechos del Hombre y del Ciudadano que, con sus especificidades, se recogen en las formulaciones americana y francesa remiten, en última instancia, a la libertad e igualdad de todo hombre, por lo que no son derechos exclusivos de los miembros de una sociedad particular, sino que deben aplicarse jurídicamente en toda sociedad que se jacte de cumplir las exigencias morales que concierne a cualquier hombre. A este respecto, para Habermas, "los derechos fundamentales liberales y sociales tienen la forma de normas generales que se dirigen a los ciudadanos en su calidad de «seres humanos» (y no solamante como miembros de un Estado) (y) aunque [...] se hacen efectivos en el marco de un ordenamiento jurídico nacional, fundamentan en ese marco de validez derechos para todas las personas, no sólo para los ciudadanos" $(1997,81)$. De esta manera se avanzaría en el proceso de disolución de la diferencia entre derechos del hombre y derechos del ciudadano.

Desde esta posición, la ciudadanía liberal se concibe como un estatus mucho más que como una práctica política. Este ciudadano -como consecuencia de sus prioridades y predilecciones- ya tiene preferencias prepolíticas, desde donde percibirá que las leyes o las reglas sociales son constricciones a su

13 Esta cosmovisión subyace tanto en la "Declaración de derechos del buen pueblo de Virginia" (12-06-1776), que parte de que "todos los hombres son por naturaleza igualmente libres e independientes y tienen ciertos derechos innatos" como en la "Declaración de los derechos del hombre y del ciudadano" (Francia, 1789), que se refiere siempre a los derechos del hombre. 
voluntad, hasta el punto que únicamente las aceptará como un instrumento "tolerable" para encauzar los intereses contrapuestos que se plantean en la sociedad.

Por consiguiente, para el ciudadano liberal la actividad cívica será un mal necesario, limitando sus obligaciones al respeto de los derechos ajenos y a la obediencia a las leyes emanadas de una autoridad estatal. Además, sus actividades como ciudadano se ajustan al patrón de la racionalidad económica, exigiendo tanto el cumplimiento de los contratos como el ejercicio de su capacidad de elección, hasta el punto de que la única justificación que podría encontrar en cualquier comportamiento solidario que implicara algún modo de Estado de Bienestar tendría que ver más con la mejor satisfacción de las demandas del ciudadano-consumidor.

En definitiva, la obligación política exigible a un ciudadano de estas características es la debida a las leyes, en cuanto garantes de los derechos y las libertades individuales, y siempre condicionado y ubicado dentro del marco de elección y deliberación individual. En definitiva, el liberalismo plantea expectativas débiles respecto al comportamiento de los ciudadanos, ya que mantienen una relación instrumental con la comunidad política, en tanto ésta no es sino el medio para servir a los individuos y dotarles de libertad y seguridad, con el fin de que cada uno encuentre su propia satisfacción o felicidad.

\section{LA COMUNIDAD REPUBLICANA Y EL COMPROMISO CÍVICO}

El republicanismo político concibe que la teorización sobre los derechos no tiene porqué entenderse forzosamente en un sentido iusnaturalista, esto es, que los derechos reconocidos en la comunidad política derivan de los derechos naturales del hombre, anteriores y superiores, fundándose en ellos la legitimidad de cualquier derecho positivo; sino que considera, más bien, que cabe pensar una posición de cooriginariedad entre los derechos del hombre y los derechos del ciudadanos, en tanto estos últimos son derechos establecidos en virtud de la voluntad del proceso democrático. entre los derechos del ciudadanos, como derechos establecidos en el proceso democrático, y los derechos del hombre.

Al dar significación destacada a la voluntad política expresada en el proceso democrático, el "sistema de los derechos recoge [...] las condiciones bajo las que pueden institucionalizarse jurídicamente las formas de comunicación necesarias para una producción de normas políticamente autónoma" (Habermas 1998, 169). Desde este punto de vista, por una parte, son derechos particulares (en cuanto que son consecuencia de la deliberación y decisión política de los miembros de una comunidad política determinada), pero, por otro lado, en 
cuanto "condiciones necesarias que no hacen más que posibilitar el ejercicio de la autonomía política [...] y como condiciones posibilitantes (que) no pueden restringir la soberanía del legislador, aun cuando no estén a disposición de éste" (Habermas 1998, 194), también son derechos universales (en cuanto constituyen las facultades y condiciones que requiere cualquier sujeto político capaz de una plena participación en el proceso democrático de determinación y decisión).

En esta línea, ya "la Declaración de Derechos del Hombre y del Ciudadano nacida de la Revolución francesa proclamaba un principio de universalidad cívica que debía realizarse en el seno de cada comunidad política, no en una imaginaria cosmópolis" (Colom 1998, 41). Y en ese imaginario de universalidad cívica ilustrada se elaboró un concepto de fraternidad política que tuvo su momento más álgido en el periodo que gobernó la fracción jacobina. Haciendo referencia a Gauthier (2014), Domènech (2004) y Belissa (1998), Puyol señala que en ese tiempo la fraternidad, apelando a que todos somos hermanos de una misma humanidad y como forma de liberación de los misérables, "prometía la abolición legal de todos los contratos feudales de servidumbre y la promesa de que ningún ciudadano o ser humano -que en la Declaración Universal de los Derechos del Hombre y del Ciudadano de 1789 venía a ser lo mismo- acabaría dominando a otro jurídica, social o económicamente $(2018,5)$.

Pero si la fraternidad política no tuvo el éxito político que la fracción más radical más jacobina pretendía, y que fue víctima de su propia visceralidad personifica en la guillotina, sí consiguió privilegiar una concepto (el ciudadano) que, a través de una reinterpretación del imaginario republicano romano, adquirió con la Revolución francesa una dimensión y un contenido aglutinante exitoso, hasta el punto de definir la comunidad política republicana como una expresión de la identidad cívica. Es decir, como aquella concepción de la vida política que preconiza un orden democrático dependiente de la vigencia de la responsabilidad pública de la ciudadanía. Por ello, su institución fundamental es precisamente la de ciudadanía, en su doble sentido ${ }^{14}$ : como conjunto de miembros libres de la sociedad política y como la condición que cada uno de ellos ostenta en tanto que componente soberano del cuerpo político.

Lo que aquí más interesa del republicanismo político (coincidente también -con matices- con el comunitarismo político que señalaré más adelante) es la crítica a la concepción individualista del liberalismo y a su concepción puramente procedimental de la comunidad política, siendo éste el aspecto donde el

14 Este doble sentido de membrecía que tiene la ciudadanía se exterioriza con dos expresiones distintas en otros idiomas, caso del inglés (citizenship/citizenry) como del alemán (Bürgerschaft) Bürgertum). 
ciudadano republicano estará más dispuesto a asumir responsabilidades y obligaciones comunes, en tanto percibe a sus compatriotas como conciudadanos que comparten un mismo destino, aunque siempre sujeto a la voluntariedad y al diálogo con la comunidad viviente, hasta la circustancia de interpretar "instrumentalmente" sus propias tradiciones (Gargarella 1999, 178-180). En este sentido, el republicanismo concibe la ciudadanía principalmente como práctica política, como forma de participación activa en la cosa pública. No se asienta sobre la primacía ontológica del individuo, ni sobre la defensa de sus derechos particulares, sino sobre un modo de vida compartido. De hecho, desde el republicanismo no se habla de "derechos naturales", sino de derechos ciudadanos, es decir, derivados de acuerdos y normas: son resultados de un proceso político, y no su presupuesto. La igualdad y los derechos están, por tanto, basados en el autogobierno, que requiere de la participación activa de la comunidad política. Desde este punto de vista, más que en derechos, la ciudadanía republicana se basaría en deberes ${ }^{15}$, que serían la base de los derechos: puesto que la libertad depende de la acción común, los ciudadanos tienen el deber de comprometerse con lo público, así como respetar la esfera de acción libre que corresponde legítimamente a sus conciudadanos.

Todo ello implica compromiso cívico (virtud cívica), que es la obligación política democrática o republicana, "compuesta de tolerancia, espíritu público, exigencia de información: es decir, una cierta sed de saber qué pasa en la esfera pública. Está compuesta, también, por una medida de confianza en la capacidad propia y la de la ciudadanía para intervenir y modificar - siquiera marginalmente- para mejorar las condiciones de la vida compartida." (Giner 1998, 81). Por tanto, la obligación política del compromiso cívico acarrearía en el republicanismo la solidaridad hacia los conciudadanos.

Si la polis griega identifica comunidad política con comunidad moral (profundizaremos en ello al hablar de comunitarismo), la república, en cambio, se constituye como comunidad de derechos que iguala a sus integrantes por el estatuto jurídico de la ciudadanía, propugna la solidaridad cívica entre los conciudadanos y alecciona a la lealtad hacia las instituciones que la hacen posible. En

15 Skinner (1984), por citar un autor que se reivindica de este modelo, estima que la libertad individual no puede percibirse sin una moción del bien común, que se asegura en una comunidad libre y que solamente con la participación cívica y activa en la vida política de la comunidad puede alcanzarse. Estudioso del republicanismo clásico, Skinner (1992) considera que los valores encarnados por la virtud republicana emanan de la filosofía moral romana, en el que sobresalen figuras relevantes como Cicerón, Tito Livio o Salustio (en este orden); que su testigo fue recogido en las ciudades-estado italianas y particularmente por Maquivelo; siendo posteriormente reivindicado por Harrington. Milton y otros republicanos ingleses de la revolución del diecisiete, para activarse finalmente en el siglo dieciocho en la disidencia y oposición a la monarquía absoluta francesa, donde destaca la figura de Montesquieu. 
definitiva -primando la integración política y compatibilizándola con el pluralismo moral, cultural y étnico- el patriotismo republicano se traduce en una adhesión a la ley y al sistema político que hacen posible el ejercicio de la libertad civil y la solidaridad.

\section{LA COMUNIDAD COMUNITARISTA Y LA LEALTAD NACIONAL}

En líneas generales se puede afirmar que el modelo comunitarista considera que es la identidad comunal la razón de ser de la comunidad política. El sujeto político principal no es el individuo, sino la comunidad, una comunidad considerada natural o de pertenencia. Aunque hay distintos comunitarismos, al objeto de señalar algunas características de este modelo, voy a referirme a uno ellos, al nacionalismo - por ser probablemente el caso más destacado-, donde, a través del principio de la nacionalidad, se enfatiza el grupo cultural o étnico, se ejercita la solidaridad entre quienes comparten una historia o tradición, y se apela a la defensa y al mantenimiento de la identidad para legitimar la existencia del Estado.

Para los comunitaristas, en las modernas sociedades occidentales, concebidas como agregados de individuos con planes de vida propios y en la que cualquier invocación a algo como el "bien de la comunidad" es vista con recelo, se habrían deshecho, por tanto, las redes de solidaridad y compromiso social que la cohesionaban. Y todo ello nos habría conducido a "la fragmentación, esto es, un pueblo cada vez menos capaz de formar un propósito común y llevarlo a cabo. La fragmentación aparece cuando las personas llegan a verse a sí mismas cada vez más atomísticamente y cada vez menos ligadas a sus conciudadanos en proyectos comunes y lealtades" (Taylor 1997, 365-366).

En las antípodas de esta tendencia individualista y disgregadora, los comunitaristas consideran que el yo siempre es un yo situado en una sociedad particular, en una situación histórica concreta. Ese "yo histórico" engendra deberes de lealtad hacia las familias, los grupos y las naciones que participan de la definición de nuestro yo. Estos deberes pueden ser comprendidos como una expresión de autoestima o de aceptación de uno mismo. Para aceptarme o amarme a mí mismo, debo respetar y querer los aspectos de mí mismo que están ligados a los otros. De este modo, mi simple biografía crea obligaciones hacia otras personas, obligaciones que yo debo retribuir asumiendo deberes y compromisos de lealtad y correspondencia hacia los míos, como miembros de una fraternidad originaria que compartimos un mismo destino. Este es el reino de la hermandad, repleta de "metáforas familiares". Y aplicando el modelo de una familia 
ampliada, también la sociedad vendría a ser como una sucesión de círculos concéntricos, con el Estado como círculo máximo. Así, formando círculos concéntricos, las distintas comunidades, desde la familia a la nación, mantienen una continuidad cualitativa con diferencias derivadas únicamente de la frecuencia de encuentros o relaciones, no de los valores. A lo largo de las distintas escalas, el cemento que mantiene la unidad es la participación en la misma idea de bien.

Para los comunitaristas, la socialización moral de los individuos tiene lugar en el seno de una comunidad particular. Igualmente, la adquisición de la competencia linguística se plasma en el aprendizaje de una lengua concreta, y no del lenguaje como tal. Del mismo modo, el desarrollo personal de los juicios morales y políticos nacería en el seno de una moralidad concreta, y no a partir de una eticidad abstracta. Si para los liberales la universalidad y generalidad que caracteriza a las reglas morales se alcanza elevándose por encima de la particularidad social en la que se originan, para los comunitaristas estas reglas morales se alcanzan a partir de los bienes específicos y relativos en virtud de los cuales se justifican.

La lealtad nacional es, pues, la debida a la comunidad. Soy fiel a una concepción común de la vida buena, a una comunidad moral y política específica, que exclusivamente puede ser asumida por quienes pertenezcan a ella. Y en el escalafón más alto reinaría el patriotismo nacional, definido como "un tipo de lealtad a la propia nación, lo que sólo aquellos que poseen esa particular nacionalidad pueden alegar" (MacIntyre 1993, 68), al que se considera como una virtud, puesto que es la condición de posibilidad para el desarrollo de la conciencia moral de los individuos.

Para MacIntyre, solamente puedo aprehender las reglas morales en la versión en que se encarnan en una comunidad específica; por lo que la justificación de la moralidad debe hacerse en los términos de los bienes particulares disfrutados en la vida de las comunidades singulares. De hecho, "sin estas particularidades morales desde las que partir, no habría ningún lugar desde donde partir" (MacIntyre 2013, 272), y precisamente "en el avanzar desde esas particularidades consiste en hacer el bien, lo universal. [...] La particularidad nunca puede ser dejada simplemente atrás o negada. La noción de escapar de ella hacia un dominio de máximas enteramente universales [...] es una ilusión de consecuencias dolorosas" $(2013,272)$.

Por tanto, si sólo puedo existir y mantenerme como agente moral a través del tipo de sustento que me permite mi comunidad, entonces resulta claro que el patriotismo, esta fraternidad en la patria, debe ser considerado una virtud, en tanto me configura y desarrolla como agente moral. En definitiva, la 
consideración de que el patriotismo es una virtud deriva, en palabras de McIntyre, de que "si [...] únicamente puedo aprender las reglas de la moral en la versión bajo la cual se encarnan en alguna comunidad en particular; [...] si [...] la justificación de la moral debe hacerse en términos de bienes determinados que se disfrutan en el seno de la vida de comunidades concretas; y si [...] uno es configurado y conservado como agente moral únicamente por medio de tipos concretos de sostén moral que mi comunidad alienta, entonces, está claro que, fuera de esa comunidad, es improbable que yo me desarrolle como agente moral" (MacIntyre 1993, 76). Por ello, al objeto de conformarme y proceder como un ser moral, es imprescindible comportarme con lealtad a esa comunidad y a lo que ella requiera de mí, porque "la lealtad a esa comunidad [...] es, desde esta perspectiva, un requisito previo para la cuestión moral" (MacIntyre 1993, 76).

\section{LA CARIDAD CRISTIANA Y LA FRATERNIDAD}

“Todo cristiano está llamado a esta caridad, según su vocación y sus posibilidades de incidir en la pólis", señalaba Benedicto XVI en su Caritas in veritate $(2009, \S 7)$. En este aspecto, la capacidad institucional -también política- de la caridad no es menos cualificada e incisiva que la que puede acarrear la práctica del liberalismo "social" (Rawls 1996) o el "igualitario" (Dworkin 1993), del mismo modo que la virtud cívica republicana o la lealtad política nacional del comunitarismo no es más enérgica que "lo que pueda ser la caridad que encuentra directamente al prójimo fuera de las mediaciones institucionales de la pólis" $(2009, \S 7)$. Y ahora que, como tantas otras veces, vivimos una crisis y un desencantamiento de la política, debemos recordar que el verdadero objeto y compromiso de la política y de sus instituciones representativas es el bien común, el cual, "cuando está inspirado por la caridad, tiene una valencia superior al compromiso meramente secular y político" (ib.) Con estas rotundas palabras, Benedicto XVI hace un profundo alegato por el compromiso ineludible del cristiano en favor de la justicia, la solidaridad y el compromiso social, lo cual "forma parte de ese testimonio de la caridad divina que, actuando en el tiempo, prepara lo eterno. La acción del hombre sobre la tierra, cuando está inspirada y sustentada por la caridad, contribuye a la edificación de esa ciudad de Dios universal hacia la cual avanza la historia de la familia humana" (id).

Con este exhorto a la misericordia y llamamiento a la universalidad, El Santo Padre está poniendo el dedo en la llaga ante el modo y la exigencia de afrontar el gran reto de nuestros días, que en "una sociedad en vías de globalización, el 
bien común y el esfuerzo por él, han de abarcar necesariamente a toda la familia humana, es decir, a la comunidad de los pueblos y naciones”. $(2009, \S 7)$

Porque la globalización es una realidad omnipresente en nuestras vidas y prácticas personales y sociales. Desgraciadamente, frente a la insistente y reiterada apologética que propugnaba que el despliegue de la globalización traería consigo un incremento de las oportunidades de bienestar, los hechos indican todo lo contrario. Por ello, si "la expansión capitalista no implica ningún resultado que pueda identificarse en términos de desarrollo, (...) y en modo alguno implica pleno empleo o un grado predeterminado de igualdad en la distribución de la renta" (Amin 1999, 30), entonces, nos estamos enfrentando a un problema que, con graves consecuencias de integración social, atañe a la esencia misma de la noción de ciudadanía, lo que nos obligará a encarar la pregunta de si el mero reconocimiento formal de la igualdad jurídica, sin la garantía de unas condiciones mínimas, resulta suficiente para que todos los ciudadanos puedan gozar y ejercitar los derechos civiles y políticos en plenitud; todo lo cual, si es preocupante en el primer mundo, estas desigualdades se convierten en escandalosas e ignominiosas en cuanto nos referimos a los países pobres y subdesarrollados, como se denuncia tantas veces en el Compendio de la Doctrina Social de la Iglesia al que me he referido con anterioridad (CDSI, 2005, §192), en la línea con lo señalado en varias encíclicas papeles y documentos eclesiásticos.

A fin de evitar, tomando el símil hobbesiano, el estado de "guerra de todos contra todos" anterior a una organización social acordada y justa, en la búsqueda del bien común y con el propósito de paliar en parte las desigualdades sociales y garantizar unas condiciones de vida dignas para todos los ciudadanos dentro de cada Estado, Contreras sostiene que "allí donde no hay una intervención correctora de los poderes públicos, la libertad se convierte en coartada para la explotación de los débiles y la igualdad formal deviene cobertura ideológica de la desigualdad material. Los derechos sociales han sido introducidos precisamente para enmendar este despropósito; la política social del Estado debe ser, por tanto, un agente compensador- nivelador que contrarreste (en parte) la dinámica de desigualdad generada por la economía de mercado" $(1994,26)$.

Se aboga, por tanto, por realizar un esfuerzo para que todos los miembros de la sociedad cuenten con una situación material que les permita gozar y ejercitar su igualdad jurídica; y corresponde al Estado cumplir ese objetivo social. Este objetivo está en la línea de lo manifestado por Benedicto XVI cuando señala que "una norma fundamental del Estado debe ser perseguir la justicia y que el objetivo de un orden social justo es garantizar a cada uno, respetando el principio de subsidiaridad, su parte de los bienes comunes. Eso es lo que ha subrayado 
también la doctrina cristiana sobre el Estado y la doctrina social de la Iglesia". (Deus caritas est, 2005c, §27)

Éste precisamente ha sido el reto que han asumido los Estados que se denominan sociales, responsabilizándose de este compromiso bajo la denominación del Estado de bienestar, allí donde se han dado condiciones para llevarlo a cabo. Con todo, actualmente no circulan los mejores vientos para sostener los enormes gastos que supone mantener hoy en día un Estado de bienestar, que ha sido el buque insignia de un modelo social en la parte más desarrollada económicamente de Europa. Con todo, no siendo el objeto de este artículo plantear el debate sobre las condiciones para mantener actualmente un Welfare State sostenible, únicamente quería plantear la pregunta de si los gastos para el Estado de bienestar deben ser considerados consumo social o inversión social, además de constatar que el viejo welfare state está mostrando en nuestros días una enorme incapacidad a fin de marcar pautas ante los actuales modelos de pobreza, al tiempo que manifiesta igual impotencia para afrontar el continuo aumento las desigualdades sociales en Europa.

Si a todo ello le añadimos que la aplicación de un fuerte sistema impositivo -como mecanismo clásico para la redistribución- ha producido una ralentización del crecimiento, y si como consecuencia de ello los gobiernos han tenido que recurrir a un excesivo (y en ocasiones irresponsable) endeudamiento de los Estados, nos encontramos ante una verdadera crisis del Estado de bienestar con una más que evidente limitación de recursos para la intervención social de los gobiernos. Ante ello, y si seguimos considerando que la redistribución es un elemento fundamental para abordar la integración social, hoy es más urgente que nunca encarar el reto para proceder a redefinir un nuevo welfare.

Por eso, más allá de los modelos de comunidad política y las obligaciones que éstas puedan generar y con anterioridad a las propuestas que se puedan formular para encauzar la acción social de los gobiernos, Benedicto XVI hace un llamamiento a no olvidar la finalidad de la política, cuando señala que "la justicia es el objeto y, por tanto, también la medida intrínseca de toda política. La política es más que una simple técnica para determinar los ordenamientos públicos: su origen y su meta están precisamente en la justicia, y ésta es de naturaleza ética" 2005c, §28). Por ello, si de justicia y dignidad se trata, y en aras a garantizar el desarrollo integral de la persona y fomentar sus capacidades, Sen sugiere que de cara a cuantificar las necesidades se traslade la referencia a los bienes y servicios que hay que poner a disposición de los beneficiarios por el de la efectiva capacidad que éstos evidencian de desarrollarse debido a su aprovechamiento. Con esta declaración, Sen expone la cuestión de la importancia de 
las capacidades (1985) para el bienestar de las personas, y lo expresa con dos enunciados diferentes pero interrelacionadas. El primero se refiere a la capacidad intrínseca que poseen los seres humanos como atributo de su libertad, y lo formula como sigue: "si los funcionamientos alcanzados constituyen el bienestar de una persona, entonces la capacidad para alcanzar (éstos) [...] constituirá la libertad de esa persona, sus oportunidades reales para obtener bienestar" $(1999,54)$. El segundo enunciado, por su parte, señala que el propio bienestar alcanzado está condicionado a la capacidad de aprovechamiento que se disponga, esto es, "en hacer depender el propio bienestar alcanzado de la capacidad" (1999, 55), con lo que "el hecho de poder elegir debería entenderse como un componente valioso de la existencia" (ib.), hasta el punto de que "una vida de elecciones genuinas con opciones serias puede considerarse, por esta razón, más rica" (ib.). En definitiva, lo que es relevante para Sen, más allá de lo que se pueda lograr, reside en la propia capacidad de elegir, en la libertad de poder optar.

Aunque "la Iglesia no puede ni debe emprender por cuenta propia la empresa política de realizar la sociedad más justa posible [...] ni debe sustituir al Estado" (Benedicto XVI 2005c, §28), camina junto a toda la humanidad y debe dar testimonio de la caridad de Cristo, por lo que "tampoco puede ni debe quedarse al margen en la lucha por la justicia” (2005c, §28)

Y este canto a la justicia, a la libertad y al desarrollo integral humano ya sido proclamado desde tiempos pretéritos por las máximas autoridades de la Iglesia, apelando al ejercicio de la responsabilidad para su desempeño. Ya se señalaba nítidamente en la Populorum progressio (1967) y lo vuelve a recoger Benedicto XVI, "esta libertad se refiere al desarrollo que tenemos ante nosotros pero, al mismo tiempo, también a las situaciones de subdesarrollo, que no son fruto de la casualidad o de una necesidad histórica, sino que dependen de la responsabilidad humana. [...] También esto es vocación, en cuanto llamada de hombres libres a hombres libres para asumir una responsabilidad común.” $(2009$, §17). Y continúa el Santo Padre: "Pablo VI percibía netamente la importancia de las estructuras económicas y de las instituciones, pero se daba cuenta con igual claridad de que la naturaleza de éstas era ser instrumentos de la libertad humana. Sólo si es libre, el desarrollo puede ser integralmente humano; sólo en un régimen de libertad responsable puede crecer de manera adecuada". $(2009, \S 17)$.

Las relaciones entre la religión y la comunidad política, entre la Iglesia y el Estado, constituyen una constante inevitable de la historia universal y se han desarrollado, desarrollan y desarrollarán de forma cambiante a lo largo del tiempo, porque corresponden por su propia naturaleza a un orden de realidades permanentes que se vinculan con elementos sustanciales del ser humano, tanto 
como resultado de inevitables e íntimos interrogantes a los que la persona humana no se puede substraer, como por la dimensión social de ésta, elemento constitutivo de su carácter relacional.

Muchos han sido los sucesos relevantes que recientemente han tenido lugar en la Iglesia y en el mundo de la política. La Iglesia Católica ha vivido el Concilio Vaticano II (1965), cuyo alcance ha traspasado la divisoria interna de su existencia espiritual y pastoral; y en 1978 un Papa venido de una simbólica, en varios sentidos, Polonia ha roto la tradición de monopolio italiano en el pontificado, al mismo tiempo que ha insuflado a la Iglesia de un dinamismo evangelizador sin precedentes. Igualmente la humanidad ha proseguido con su trepidante proceso globalizador, siendo muy discutibles sus consecuencias; y recientemente ha irrumpido un terrorismo islámico fundamentalista, que obliga a posicionar una vez más la relación entre lo religioso lo político.

Las relaciones entre la Iglesia y el Estado tienen un campo abonado si sus expectativas se ponen inequívocamente al servicio del bien superior de la persona humana y del bien común, ya que estos dos principios conforman el núcleo de las doctrinas jurídicas y filosófico-teológicas que se conformaron en el contexto fundacional de dos experiencias que van asociadas y que fueron medulares y fundamentales para el progreso humano: la Organización de las Naciones Unidas y el Concilio Vaticano II.

Por tanto, valorar y respetar los principios que hicieron germinar estos dos acontecimientos se revela hoy fundamental para asentar y desarrollar una labor conjunta entre instituciones que debiera resultar tremendamente beneficiosa, porque "ciertamente, las realidades temporales y las realidades sobrenaturales están estrechamente unidas entre sí" (Concilio Vaticano II, Gaudium et Spes, $1965, \S 76)$.

Así, ante, "El Estado que quiere proveer a todo, que absorbe todo en sí mismo, (que) se convierte en definitiva en una instancia burocrática" (Benedicto XVI 2005c, §28), es esencial el complemento de la Iglesia, que, basándose en la doctrina conciliar, advierte que el respeto, el cuidado y la promoción del bien integral de la persona humana constituyen para el primer y fundamental postulado que ha de regir todo el orden social y político. Por ello, cuando el Estado "no puede asegurar lo más esencial que el hombre afligido -cualquier ser humano- necesita: una entrañable atención personal." (id.), la Iglesia, comprometida en la defensa del carácter inviolable de los derechos fundamentales del ser humano -inherentes a su dignidad y fundados en du naturaleza trascendente-, es la institución más adecuada para llevar a cabo esta labor. 
De este modo, la Iglesia contribuye de una manera decisiva en la defensa, toma de conciencia social y difusión de los grandes valores e ideales, que, como son la justicia, la paz y la solidaridad, son indispensables e irreemplazables en el establecimiento y conservación de una comunidad política estable y duradera; por lo que es responsabilidad de una sociedad que se autodenomina plural permitir que la Iglesia pueda vivir y desarrollar su misión, garantizándole que pueda cumplir con su cometido en condiciones de plena libertad, tanto jurídica como social. El Concilio Vaticano II no tenía dudas al respecto: "Es de justicia que pueda la Iglesia en todo momento y en todas partes predicar la fe con auténtica libertad, enseñar su doctrina social, ejercer su misión entre los hombres sin traba alguna y dar su juicio moral, incluso sobre materias referentes al orden político, cuando lo exijan los derechos fundamentales de la persona o la salvación de las almas, utilizando todos y solos aquellos medios que sean conformes al Evangelio y al bien de todos según la diversidad de tiempos y de situaciones" (Gaudium et Spes, 1965, §76).

El Concilio Vaticano II ya dejaba clara la distinción entre Estado o Iglesia, esto es, el reconocimiento de la autonomía de las realidades temporales, del mismo modo que reafirmaba la independencia o soberanía de la Iglesia respecto a la ética y la moral. Así queda patente el mensaje de Benedicto XVI: "la sociedad justa no puede ser obra de la Iglesia, sino de la política. No obstante, (a la Iglesia) le interesa sobremanera trabajar por la justicia esforzándose por abrir la inteligencia y la voluntad a las exigencias del bien” (2005c, §28). En esta línea, apelando al principio de la libertad religiosa y cumpliendo su cometido de cooperar en la búsqueda del bien común, al igual que en virtud de las demandas contenidas en el principio de libertad religiosa, compite a la Iglesia cumplir con el aspecto medular de su cometido, esto es, comportarse como "signo y salvaguardia del carácter trascendente de la persona humana" (Gaudium et Spes, $1965, \S 76)$.

Por tanto, como acertadamente señala Benedicto XVI, "lo que hace falta no es un Estado que regule y domine todo, sino que generosamente reconozca y apoye, de acuerdo con el principio de subsidiaridad, las iniciativas que surgen de las diversas fuerzas sociales y que unen la espontaneidad con la cercanía a los hombres necesitados de auxilio" (2005c, §28). Cuando en el Concilio Vaticano II se recordaba que "la comunidad política y la Iglesia son independientes y autónomas, cada una en su propio terreno" (Gaudium et Spes, 1965, §76), se subrayaba, sin embargo, que "ambas, sin embargo, aunque por diverso título, están al servicio de la vocación personal y social del hombre" (id.), reiterando que "este servicio lo realizarán con tanta mayor eficacia, para bien de todos, 
cuanto más sana y mejor sea la cooperación entre ellas, habida cuenta de las circunstancias de lugar y tiempo" (id.).

Y para este servicio, conforme al principio de subsidiaridad, y como fuerza social y viva que sobradamente ha demostrado estar capacitada que pueda cumplir con este cometido, está la Iglesia, porque en "en ella late el dinamismo del amor suscitado por el Espíritu de Cristo. Este amor no brinda a los hombres sólo ayuda material, sino también sosiego y cuidado del alma, un ayuda con frecuencia más necesaria que el sustento material" (Benedicto XVI, Deus caritas est, 2005c, §28).

En esta misma dirección, con el deber inmediato de implicarse en favor de una convivencia más justa y armónica, los fieles laicos deben responsabilizarse en las tareas de la comunidad, porque, "como ciudadanos del Estado, están llamados a participar en primera persona en la vida pública. Por tanto, no pueden eximirse de la «multiforme y variada acción económica, social, legislativa, administrativa y cultural, destinada a promover orgánica e institucionalmente el bien común»." (Deus caritas est, 2005c, §29). De este modo, desde su vocación específica, el compromiso temporal correspondiente y sus capacidades y posibilidades, "respetando su legítima autonomía y cooperando con los otros ciudadanos" (id.), contribuirán a "configurar rectamente la vida social" (id.).

Por último, un canto a la caridad cristiana, que "ha de ser independiente de partidos e ideologías" (Deus caritas est, 2005c, §31"), "no ha de ser un medio de [...] proselitismo" (id.), ni se "practica para obtener otros objetivos" (id.), porque "siempre está en juego todo el hombre" (id.). La fraternidad cristiana, por tanto, practicada con el don de la caridad, "es un modo de servir que hace humilde al que sirve", porque "Cristo ocupó el último puesto en el mundo [...] y precisamente con esta humildad radical nos ha redimido y nos ayuda constantemente" (Deus caritas est, 2005c, §35). Nunca debemos olvidarlo: "Quien es capaz de ayudar reconoce que [...] también él es ayudado; [...] Esto es gracia" (id.), porque "no actúa fundándose en una superioridad o mayor capacidad personal, sino porque el Señor le concede este don". (id.)

La Iglesia tiene una misión que cumplir, vive en una sociedad repleta de injusticias, y sus fieles -asumiendo los compromisos que la fraternidad cristiana conlleva- no deben excluirse de ser el puntal y la simiente de una comunidad política que, promoviendo la justicia y el respeto al ser humano, persiga el "bien común". 


\section{REFERENCIAS BIBLIOGRÁFICAS}

Amin, Samir. 1999. El capitalismo en la era de la globalización. Barcelona: Paidós.

Arendt, Hannah. 1973. "Desobediencia civil”. En Crisis de la República, 67108. Madrid: Taurus.

Aristóteles. 1978. La Política. Madrid: Espasa-Calpe (Austral).

Belissa, Marc. 1998. Fraternité universalle et intérêt national: 1713-1795. Les cosmopoliques du droit du gens. Paris: Kime.

Cicerón, Marco Tulio. 1989. Sobre los deberes. Madrid: Tecnos.

—. 1994. Catilinarias. Barcelona: Planeta. Consultado el 24 agosto de 2019, http://historicodigital.com/download/ciceron\%20catilinarias.pdf

Colom, Francisco. 1998. Razones de identidad. Pluralismo cultural e integración política. Barcelona: Anthropos.

Concilio Vaticano II. 1965. Constitución Pastoral Gaudium et Spes. Roma. Consultado el 27 agosto de 2019, http://www.vatican.va/archive/hist_councils/ii_vatican_council/documents/vat-ii_const_19651207_gaudium-etspes sp.html

Consejo Pontificio “Justicia y Paz". 2005. Compendio de la Doctrina social de la Iglesia. Madrid: Biblioteca de Autores Cristianos y Editorial Planeta. Consultado el 28 agosto de 2019, http://www.vatican.va/roman_curia/pontifical councils/justpeace/documents/rc pc justpeace doc 20060526 co mpendio-dott-soc_sp.html

Contreras Peláez, Francisco José. 1994. Derechos Sociales: Teoría e Ideología. Madrid: Tecnos.

Domènech, Antoni. 2004. El eclipse de la fraternidad. Barcelona: Crítica.

Dworkin, Ronald. 1993. Ética privada e igualitarismo político. Barcelona: Paidós.

Gamper, Daniel. 2018. "Gratuidad y subsidiaridad: una mirada política a la fraternidad católica". En Libertad, igualdad y ifraternidad?, editado por Ángel Puyol, Daimon. Revista Internacional de Filosofía Suplemento 7: 2943.

Gargarella, Roberto. 1999. Las teorías de la justicia después de Rawls. Barcelona: Paidós.

Gauthier, Florence. 2014. Triomphe et mort de la révolution des droits de l'homme et du citoyen 1789-1795-1802. Paris: Syllepse.

Giner, Salvador. 1998. "Las razones del republicanismo". Claves de razón práctica 81: 2-13.

Habermas, Jürgen. 1997. "La idea kantiana de paz perpetua". Isegoría, 16 (1997): 61-90.

—. 1998. Facticidad y validez. Madrid: Trotta. 
Juan Pablo II. 1991. "Carta encíclica Centesimus annus". Consultado el 17 agosto de 2019, http://w2.vatican.va/content/john-paul-ii/es/encyclicals/ documents/hf_jp-ii_enc_01051991_centesimus-annus.html

—. 1993. "Carta encíclica Veritatis splendor". Consultado el 18 de agosto de 2019, https://w2.vatican.va/content/john-paul-ii/es/encyclicals/documents/ hf_jp-ii_enc_06081993_veritatis-splendor.html [

Kant, Immanuel. 1989. La metafisica de las costumbres. Madrid: Tecnos.

MacIntyre, Alasdair. 1984. "Is Patriotism a Virtue?" En The Lindley Lectures, 3-20. Dept. of Philosophy, University of Kansas. En español: 1993. “¿Es el patriotismo una virtud?" biTARTE 1: 67-85.

- 1987. Tras la virtud. Barcelona: Austral.

Mayhew, Robert. 1997. Aristotle's Criticism of Plato's Republic. NewYork-Oxford: Rowman and Littlefield.

Nietzsche, Friedrich. 1972. La genealogía de la moral. Madrid: Alianza.

Nogueira Alcalá, Humberto. 2003. Teoría y dogmática de los derechos fundamentales. México D. F.: Universidad Nacional Autónoma de México (Instituto de Investigaciones Jurídicas).

Pablo VI. 1967. "Carta encíclica Populorum progressio". Consultado el 20 agosto de 2019, http://w2.vatican.va/content/paul-vi/es/encyclicals/documents/hf_p-vi_enc_26031967_populorum.html

Puyol, Ángel. 201 $\overline{8}$. "Presentación. Libertad, igualdad y ifraternidad?". En $\mathrm{Li}$ bertad, igualdad y ifraternidad?, editado por Ángel Puyol, Daimon. Revista Internacional de Filosofía Suplemento 7: 5-9.

Ratzinger, Joseph. 2005a. La fraternidad de los cristianos. Salamanca: Ediciones Sígueme.

—. 2005b. Dios y el mundo: creer y vivir en nuestra época. Barcelona: Random House Mondadori.

Ratzinger, Joseph. / Benedicto XVI. 2005c. "Carta encíclica Deus caritas est". Consultado el 22 agosto de 2019, http://w2.vatican.va/content/benedictxvi/es/encyclicals/documents/hf_ben-xvi_enc_20051225_deus-caritasest.html

—. 2009. "Carta encíclica Caritas in veritate". Consultado el 23 agosto de 2019, http://w2.vatican.va/content/benedict-

xvi/es/encyclicals/documents/hf_ben-xvi_enc_20090629_caritas-inveritate.html

Rawls, John. 1996. El liberalismo político. Barcelona: Crítica.

Sen, Amartya. 1985. Commodities and Capabilities. Amsterdam: NorthHolland.

-. 1999. Nuevo examen de la desigualdad. Madrid: Alianza Editorial.

Séneca, Lucio Anneo. 1984. Cartas morales a Lucilio. 2 vols. Barcelona: Orbis. Skinner, Quentin. 1984. Maquiavelo. Madrid: Alianza, . 
-. 1992. "On Justice, the Common Good and the Priority of Liberty". En Dimension of Radical Democracy: Pluralism, Citizenship, Community, editado por Chantal Mouffe, 211-224. Londres: Verso.

Taylor, Charles. 1997. "La política liberal y la esfera pública". En Argumentos filosóficos, 335-372. Barcelona: Paidós.

Tocqueville, Alexis de. 1988. La democracia en América, 2 vol. Madrid: Aguilar.

Weber, Max. 1992. Economía y Sociedad. México D. F.: F.C.E.

Zamagni, Stefano. 2019. Fraternidad, don y reciprocidad en la Caritas in veritate. Revista Cultura Económica 19(75-76): 11-29. Consultado el 23 agosto de 2019, http://bibliotecadigital.uca.edu.ar/repositorio/revistas/fraternidaddon-reciprocidad-caritas-veritate.pdf

Esteban Anchustegui Igartua

Filosofía de los Valores y Antropología Social Facultad de Educacion, Filosofia y Antropologia Universidad del País Vasco. Avenida Tolosa, 70

20018 Donostia - San Sebastián https://orcid.org/ 0000-0002-0612-6654 